\title{
4. 結語
}

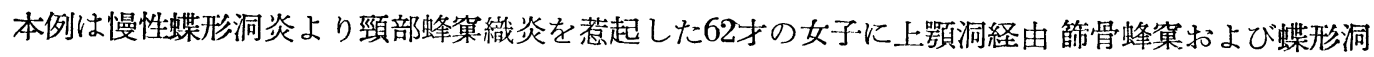
開放術を行ない，その病理組織学的検查の結果偶々上顎洞腺癌なる事を知つたが，幸いにも全治せ しめ得た症例である。

擱筆に当り御校閲の労を睗わつて恩師京大後藤教授,ならびに病理組織檡本について御教示を睗つて県立岐 皋大学医学部病理学教室汇口教授に深謝致します.

後藤： 後藤耳鼻咽喉科学

主 要 交 献

Denker u. Kahler: Handb. d. Hals usw. Bd.V.

松井：診と治 $26 ; 1$,

細谷：治療及処方 $8 ； 6$,

中村：日耳鼾 $14 ; 5$,

尾崎：日耳鼻 $42 ; 5$,

坒木：耳㬋科 10 ;

伀戸：耳番臨床 $40 ； 2 \sim 6$,

\section{外頸動脉 結 禁について

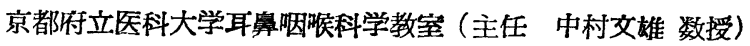 \\ 竹中文一郎山脇吉次車重雄}

\section{I 緒 言}

外頸動脉の結禁は鼻腔，咽頭，口腔の手術の際失血防止の目的で日常簡易に行われており，それ による合併症は見られないのが通常である。亜性腫潪摘出時には失血防止の外に残存腫湟組織の栄 養補給源を絶つ意味で多くの場合永久結紮が行われている.

然しながら腫湢組織が完全に摘出された時は，手術創を出来るだけ速かに正常状態に杘すために は一時的結紮が合理的である様に思われる．殊に高龄者では其の必要のある場合が多い，中村臨床 においては従来時と場合に応じて，外頸動脉の永久的あるいは一時的結紮を行つているが，一時的 結䋕に原因した合併症によつて不幸な転帰を取つた稀有な一例を経験したので報告する.

\section{II 症例}

\section{患者：67才古}

彭断：左側徧挑の癌埂,転移は認められない。血压 140/80手術は法の如く皮膚切開をなし外研動脉を露出 し上甲状腺動脉分岐值後の部で結皆を行い、喠愓組織の 完全摘出を行つて。

翌日術後約24特間てつて㭧者は高政で栄養が比較的 覀く，手術創の速かな回復をはかるために外䣆動脉の 結熬を解いて。

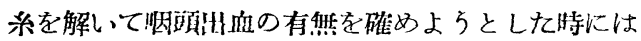

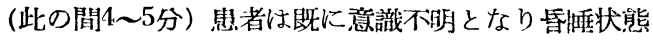
に落人り質声をあげ始めた。
右半身不随が現われ右顔面神経の㾁痺右解膜反射消 失す諗められてて・此の状態が続き患者は食慨摄取が全 く不能で, 鼻腔栄養, 栄養郕の注射で辛じて生命を保 ち術後13月日に死亡した。

副見所見：前䫓葉から側碩葉にかけ大人手拳大の 軟化巣があり周囲部には出血が認められる.(筫1図) 割断面では中大脑動脉の分布域，殊に前䫓棐に大小様 々の血栓が認められる。们組織眐本でも血栓が諮めら 机単なる资血の外に血管内に血管踥からつながつた線 維素の塊が認められした。(第2 图) 
第 1 図

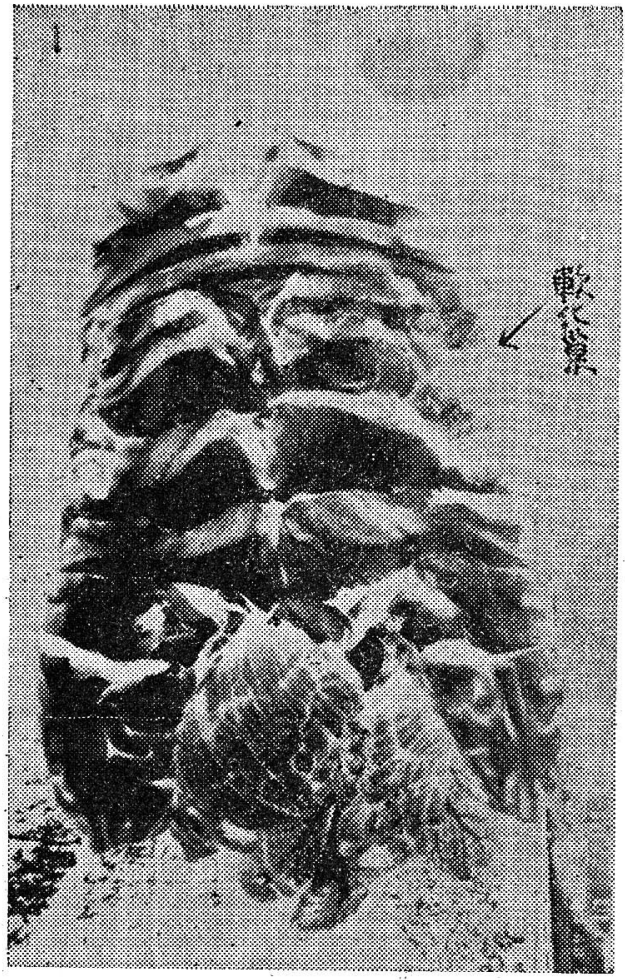

III 考
第 2 図

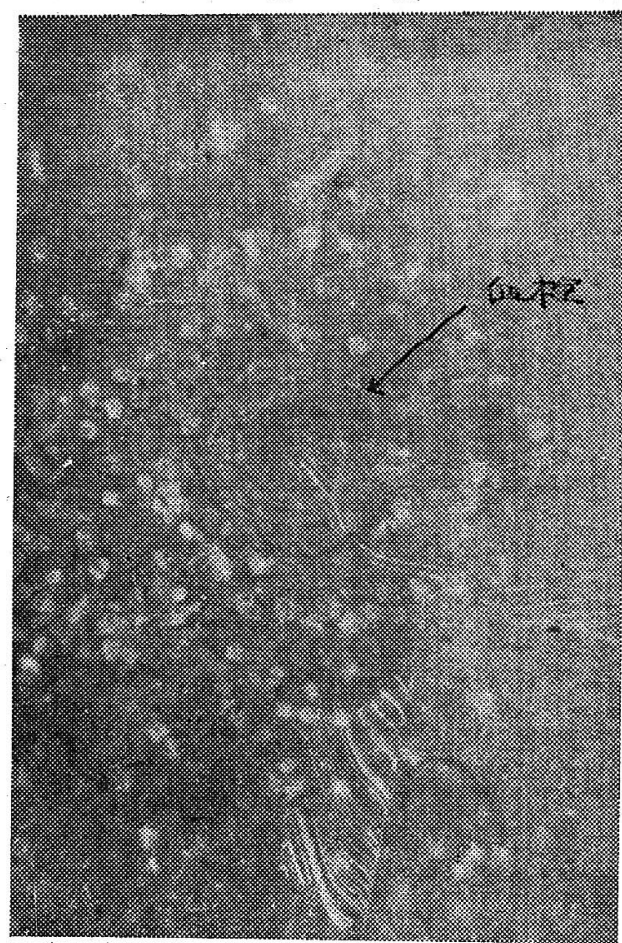

按
第， 3 図

a. carotis externa

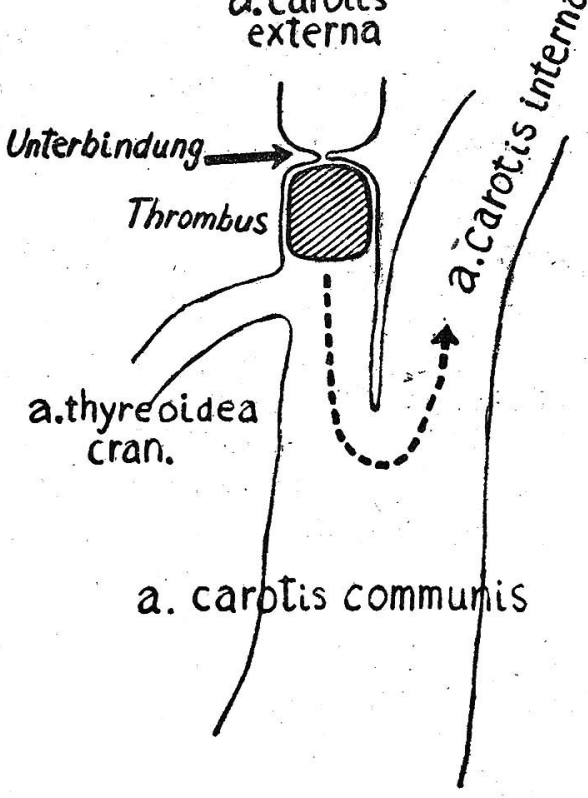

外頸動脉結禁の偶発症として考えられるのは脳症 状であるが其の頻度は極めて少なく Soerensen ${ }^{i 2}$ は

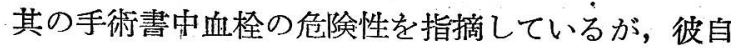
身多くの手術を行い一例子経験した事はないといつ ている. Lipps” は腫湯, 動脉瘤, 出血等各種疾患 130例に外頸動脉結禁を行い，2例の死亡例を報告し ている. 又, Heinrich ${ }^{3)}$ は右外頸動脉結禁後16日目 に左側の半身不随を生じ 4 日目に死亡, 剖見で中大 脳動脉に血栓のあつた一例と，外頸動脉 結禁後死 亡，内囊部に軟化創のあつた一例を報告し，外頸動 脉に出来た血栓は総頸動脉の分岐部をで延びていた といつている. Heinrich は血栓の危険性を避ける ためには，結禁を分肢部から出来るだけ遠方に行い 2〜3週間は絶対安静が必要であると云つている。

Stierlin u. Meyenburg(4) は甲状腺を摘出する際， 上下の甲状腺動脉を結紮し, 逆行性の血栓を中大脑 動脉に生じ，原因として，バせドーの恵者は血液凝 固能力が昂進している事を拳げている。 


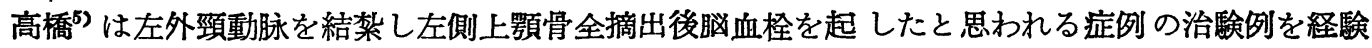
している．翻つて睬動脉血栓の原因を考えると，

（1）心臟や大動脉からのいわゆる, 逆説的栓塞症.

(2) 最も㕍々血栓の原因となるもの.

a）外頸動脉，甲状腺動脉および内頸動脉の結紮後生じた血栓.

b) 動脉硬化症.

c）閉鎖性静脉炎. (Buergeis Disease)

d）急性伝染性疾患.（チフス，肺炎）

e) 梅毒.

f）外傷.

g）周囲組織の疾患.

（3）血管周囲の腫演の外部からの圧迫.

私等の症例の血栓成因を考えると結禁を解くと同時に臨床的症状が現われたのであるから外頸動 脉結禁部に生じた血栓が何らかの理由で内頸動脉に流入し中大䋃動脉に運ばれたと解される.

外頸動脉結禁部の血栓の形成は患者の血管に動脉硬化性の変化があつた事, 結禁という機㑘的剌 韩のため血栓形成がうながされ，此の血栓が結禁糸を解く操作中に血管壁から離れ内頸動脉に流入 したものと思われる。（第 3 四）

かくして中大脳動脉に運ばれた血栓が末梢血管を栓塞し続発的に睬軟化を起したのである．睬動 脉の血栓症の予後は主として其の基礎になつている疾患如何によるものであるが，半身不随の椂な 神経症状を缺いている様な場合でも早晚, 各種の神経症状が現われて来るものである.

臨床症状の軽微な場合は脳動脉血管撮影, 眍波により狭くなつた血管の状態を知ることが出来る。 Moniz $z^{6}$ 等は, 眍腫演の矤のある500名の患者に睬動脉血管撮影を行い 4 例の血栓症をまた Elvidge

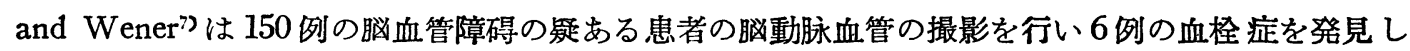
ている.

私等の症例は先に述べた原因 2 の. b. をかねそなえ其の上, 結紮を解くという事が重大な剌戟 となり大きな血栓が中大睬動脉の幹の部に栓塞し, 不幸な転㴆を取つたものと思われる。

最後に私等の経験例からいい，外頸動脉の結紮は内頸動脉分岐部よりなるベく末梢にて行い血管 性変化の多い老人では永久的結紮が良いように思 5 。

擱筆するに際し，御指導御校閲を辱うして恩師中村教授に梁射する

交

(1) Soerensen: Mund u. Halsoperation 1930

(2) Lipps: Archiv für klimische Chirurgie 1893

(3) Heinrich: Zentralblatt für Chirurgie 1926

(4) Stierlin und Meyenburg: Deutsche Zeitschrift für Chirurgie 1920
嘀

(5) 高橋：神戸医科大学釈要 3 ; 4,

(6) Moniz: Presse Med : 45 : 997. 1937

(7) Elvidge and Wener: Archives of Neurology \& psychiatry 752 (6) 1951 